\title{
2021 Handbook of Florida Water Regulation: Federal Insecticide, Fungicide, and Rodenticide Act $^{1}$
}

\author{
Michael T. Olexa, Tatiana Borisova, and Jana Caracciolo²
}

\section{Preface}

This handbook is designed to provide an accurate, current, and authoritative summary of the principal federal and state (Florida) laws that directly or indirectly relate to agriculture. This handbook provides a basic overview of the many rights and responsibilities that farmers and farmland owners have under both federal and state laws as well as the appropriate contact information to obtain more detailed information. However, the reader should be aware that because the laws, administrative rulings, and court decisions on which this handbook is based are subject to constant revision, portions of this publication could become outdated at any time. Several details of cited laws are also left out due to space limitations. This handbook is provided as an educational text for those interested in water use and water resource issues in Florida.

This handbook is distributed with the understanding that the authors are not engaged in rendering legal or other professional advice, and the information contained herein should not be regarded as a substitute for professional advice. This handbook is not all inclusive in providing information to achieve compliance with the federal and state laws and regulations governing water protection. For these reasons, the use of these materials by any person constitutes an agreement to hold harmless the authors, the UF/IFAS Center for Agricultural and Natural Resource Law, and UF/IFAS Extension for any liability claims, damages, or expenses that may be incurred by any person as a result of reference to or reliance on the information contained in this handbook. Note: UF/IFAS is the acronym for University of Florida, Institute of Food and Agricultural Sciences.

\section{FIFRA Overview}

The Federal Insecticide, Fungicide, and Rodenticide Act (FIFRA) was originally passed in 1947 and significantly amended in the 1970s. These and subsequent amendments regulate all phases of pesticide sale, use, handling, and disposal. In 1996, the federal Food Quality Protection Act (FQPA) again amended FIFRA, especially the process of establishing tolerances for pesticide residues in food and feed (see FE589). The Florida Legislature also enacted the Florida Pesticide Law (FPL) for the purpose of regulating the distribution, sale, and use of pesticides in Florida and to protect people and the environment from the adverse effects of pesticides (see FE590).

\section{Who enforces FIFRA?}

FIFRA, which is administered by the United States Department of Environmental Protection Agency (EPA), specifies that states are to have primary enforcement responsibility if they demonstrate to EPA that they have adopted adequate regulations and enforcement mechanisms. Florida has entered into several cooperative agreements with EPA and

1. This document is FE588, one of a series of the Food and Resource Economics Department, UF/IFAS Extension. Original publication date October 1998. Revised June 2017 and April 2021. Visit the EDIS website at https://edis.ifas.ufl.edu for the currently supported version of this publication.

2. Michael T. Olexa, professor, Food and Resource Economics Department, and director, UF/IFAS Center for Agricultural and Natural Resource Law, and member of The Florida Bar; Tatiana Borisova, associate professor, Food and Resource Economics Department; and Jana Caracciolo, student, Levin College of Law; UF/IFAS Extension, Gainesville, FL 32611.

The Institute of Food and Agricultural Sciences (IFAS) is an Equal Opportunity Institution authorized to provide research, educational information and other services

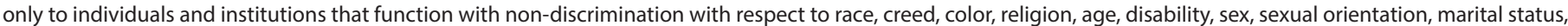

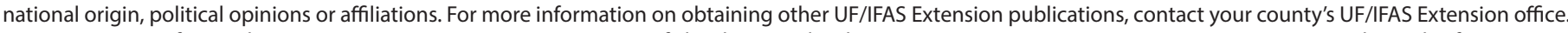
U.S. Department of Agriculture, UF/IFAS Extension Service, University of Florida, IFAS, Florida A \& M University Cooperative Extension Program, and Boards of County Commissioners Cooperating. Nick T. Place, dean for UF/IFAS Extension. 
now shoulders the responsibilities for testing and training permit applicants, with EPA in a supervisory position. Although EPA regulates the federal registration of pesticides and the monitoring of pesticide producers, states are allowed to impose regulations on pesticide sales and uses so long as those regulations do not allow any activity that violates FIFRA. If a complaint is made to EPA concerning state regulation of pesticides, EPA can give a state notice of the complaint, and if the state fails to take adequate remedial action within 90 days, EPA can rescind the state's enforcement power.

When a pesticide or device is deemed to be in violation of FIFRA requirements, EPA has the authority under FIFRA to issue a "stop sale", use, or removal order.

\section{What is the FIFRA definition of pest?}

The term "pest" includes insects, rodents, nematodes, fungus, weeds, terrestrial and aquatic plants, viruses, bacteria, and any other living organism that EPA designates as a pest.

\section{What is the FIFRA definition of pesticide?}

The term "pesticide" is broadly defined within the meaning of FIFRA as (a) any substance used to regulate, prevent, repel, or destroy any pest or plant; (b) any substance or mixture of substances intended for use as a plant regulator, defoliant, or desiccant; or (c) any nitrogen stabilizer. Note: Pesticide, however, shall not include any article that is considered an "animal drug" (or an animal feed containing or bearing an animal drug). New animal drugs are regulated by the federal Food, Drug, and Cosmetic Act (FDCA), and all other animal drugs are regulated by the Secretary of Health and Human Services.

\section{What do pesticide labels mean?}

One of the most significant aspects of FIFRA is labeling requirements. Under FIFRA, pesticides must clearly and prominently list the following information on its label:

- The name, brand, or trademark product sold under

- The name and address of producer or registrant

- The ingredients

- Instructions for use

- Net contents

- Use classification

- The EPA registration number

- Producing establishment's number
- All necessary warnings or restrictions

FIFRA requires strict compliance with the instructions printed on all pesticide labels. Labeling changes must meet National Institute for Occupational Safety and Health (NIOSH) requirements. For a complete list of all NIOSH labeling requirements in further detail, see 40 CFR 156.10 (Labeling Requirements). Pesticide labels are important because they are a central tool of enforcing FIFRA and state laws (see FE590).

\section{Which pesticides need registration?}

FIFRA requires that all pesticides be registered with EPA before they may be sold, distributed, or used. A pesticide's registration may be canceled by EPA if it is found to be harmful. For more information about EPA's cancellation policy, see https://www.epa.gov/pesticide-tolerances/ pesticide-cancellation-under-epas-own-initiative.

States may impose additional conditions on pesticide use where special problems related to their use are encountered. Pesticides are divided into two categories, general and restricted use, based on the potential for adverse effects. Some pesticides can be classified for both general and restricted use.

\section{Who may apply general-use pesticides?}

General-use pesticides may be applied by anyone and no permit is required although the user must still comply with labeling requirements, label instructions, and other regulations.

\section{Who may apply restricted-use pesticides?}

Restricted-use pesticides may be applied by three categories of applicators as follows:

1. Private applicators-apply pesticides in producing an agricultural commodity on their own lands or on lands under their control. Private applicators must be licensed to use pesticides.

2. Commercial applicators - apply pesticides to other people's lands in exchange for a fee. Commercial applicators are required to be licensed to use pesticides.

3. Experimental-use applicators (usually manufacturers or researchers) - test unregistered pesticides for potential registration. Experimental use applicators must have an experimental-use permit to test unregistered pesticides.

Restricted-use applicators are required by the state to keep records of their use of restricted-use pesticides for a period 
of 2 years under the federal Food, Agriculture, Conservation and Trade Act (FACT).

All categories of restricted-use applicators must know the regulatory restrictions to avoid adverse effects on the environment. The state can require specific minimum training for all applicators.

Each permitting category is subject to separate testing and certification procedures and may be subject to different penalties for violations.

For a complete list of Restricted-use pesticides, please see the EPA website: https://www.epa.gov/ pesticide-worker-safety/restricted-use-products-rup-report.

\section{What are the rules for storing and disposing of pesticides?}

The FIFRA requirements for adherence to label instructions also extend to the storage and disposal of pesticides. Furthermore, pesticides often fall within the "hazardous waste" classifications of the Resource Conservation and Recovery Act (RCRA) and are usually subject to "solid waste" disposal regulations. The RCRA (FE583) and FIFRA (FE588) sections of this Handbook of Florida Water Regulation should be reviewed before storing or disposing of any pesticides.

EPA provides guidelines for the storage and disposal of pesticides that, while not mandatory, are helpful in dealing with the specifics of locating storage sites, protecting groundwater, and avoiding environmental contamination.

\section{What are the penalties under FIFRA?}

Commercial applicators, wholesalers, dealers, retailers, registrants, or distributors who violate FIFRA or their permits are subject to civil fines of up to $\$ 5,000$ per offense. No civil penalties can be assessed against these parties without a hearing. They are also subject to criminal penalties of $\$ 25,000$ or imprisoned for not more than one year, or both.

Private applicators are entitled to a written warning. First violations by private applicators, who use or hold registered pesticides or use dilutions of registered pesticides only to provide a service of pest control in violation of FIFRA, are punishable by a civil penalty of up to $\$ 500$; subsequent violations may be punished by a fine of up to $\$ 1,000$. Knowing violations may bring criminal fines of $\$ 1,000$ or imprisoned for not more than 30 days, or both.
Producers of pesticides, registrants, and applicants for registration, who knowingly violate FIRFA, are subject to criminal penalties of up to $\$ 50,000$ or imprisoned for not more than one year, or both. However, no private right of action exists under FIFRA regulations. Employers may also be assessed for the violations of their employees or agents acting on their behalf.

In addition, violators of FIFRA may also be subject to penalties under the federal Food, Drug, and Cosmetic Act (FDCA); Resource Conservation and Recovery Act (RCRA); and Occupational Safety and Health Act (OSHA).

Pesticide drift and runoff containing pesticides are major water pollutants from nonpoint sources. These chemicals can enter and contaminate water, killing fish and wildlife, poisoning food sources, and destroying the habitat of animals. Careless use and/or disposal of pesticides can lead to violations, liability, and penalties under several of the acts and programs discussed in this handbook. To reduce nonpoint source contamination from pesticides and liability for contamination, pesticide users can apply Integrated Pest Management (IPM) techniques based on specific soils, climate, pest history, and crop for a particular field. IPM helps to minimize the need for pesticide use and manages necessary applications to minimize pesticide movement from the land. More information about IPM in Florida can be found at https://edis.ifas.ufl.edu/ topic_pest_management.

\section{Who is exempt from FIFRA?}

No pesticides, devices, or active ingredients used in producing pesticides intended only for export to a foreign country will be deemed a violation of FIFRA when they are prepared or packaged according to the directions of the foreign purchaser. Exception is that producers of such pesticides, devices, and active ingredients used in producing pesticides will be subject to the storage, disposal, transportation, registration, and recordkeeping provisions of FIFRA. In the case of a pesticide not registered under FIFRA or sold from existing stocks and whose registration is suspended or cancelled if, prior to export, the foreign purchaser has signed a statement acknowledging that the purchaser understands that such pesticide is not registered for use in the United States and cannot be sold in the United States under FIFRA. A copy of this statement is to be transmitted to the appropriate government official of the importing government. 
The Administrator of EPA may, at his or her discretion, exempt any federal or state agency from any provision of FIFRA if the Administrator determines that emergency conditions exist which require such an exemption. In determining whether or not such emergency conditions exist, the Administrator must consult with the Secretary of Agriculture and the governor of any state concerned if they request such a determination.

For the latest list of exemptions from FIFRA, please contact EPA.

\section{Sources}

7 United States Code, Sections 136 to $136 y$

40 CFR 156.10

\section{Acknowledgments}

The authors are indebted to the personnel of both state and federal agencies who provided their time and advice in the preparation of this handbook. We acknowledge Carol Fountain and Susan Gildersleeve at the University of Florida for their assistance in editing this handbook. We also acknowledge funding received for updating this publication from the James S. and Dorothy F. Wershow UF/ IFAS Center for Agricultural and Natural Resource Law Endowment. 